\title{
AVP-025＼cjkstart腹腔鏡下根治的前立腺全摘術における3 次元立体内視鏡の有用性
}

西宮市立中央病院泌尿器科1), 兵庫医科大学泌尿器科 ${ }^{2)}$, 神戸市立医療センター中央市民病院3), 九州大学大学院医学
研究院先端医療医学教室

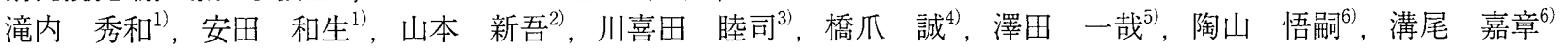
【目的】泌尿器科で行われる腹胿鏡手術の中で、腹胿鏡下前立腺全摘術は難易度の高い手術である。腹腔鏡下腎摘術な どの他の手術と比較して、縫合操作が多い点や神経血管束を温存する際に適切な層に入ることが難しい点などがその要 因と考えられる。米国では手術ロボットを用いた手術が標準となりつつあるが、手術器具の高い自由度の以外に、術者 への立体視機能も大きく関与しているものと考えられる。今回、我々は 3 次元内視鏡を用いて施行した腹腔鏡下前立腺 全摘術の 2 例の経験を報告する。【方法】対象症例は臨床病期 T2N0M0 の男性 2 名 (62 歳、72歳)。前立腺へは腹膜外 的に到達し、順向性に処理を行った。両眼に別々の映像情報を伝達するための二組のレンズ機構を有する新興光器製の 2 眼式 3D 立体内視鏡システムを用い、その画像投影にはパナソニックグループが開発した、ドーム型スクリーン（開 口径 $600 \mathrm{~mm}$ ）を用いた偏光方式立体映像提示システムを使用した。このシステムにより、室内灯をつけたままでも、 手術スタッフ全員での立体視が可能であった。また、立体視の利点を最大限に活用するために、縫合操作の際に、鉗子 尖端部付近に関節機能を有する 6 自由度外径 $5 \mathrm{~mm}$ の Cambridge Endo 社製の手術器具を使用した。通常の $2 \mathrm{D}$ 内視鏡 を用いて行われた症例群 $(\mathrm{n}=8)$ と $3 \mathrm{D}$ 内視鏡を用いて施行された症例群 $(\mathrm{n}=2)$ に扮ける手術時間、出血量、術後尿 道カテーテル抜去までの期間を比較検討し、さらに、術者、第 1 助手、第 2 助手の $2 \mathrm{D}$ 内視鏡手術と $3 \mathrm{D}$ 内視鏡手術に 対する主観的優劣判定を行った。【成績】 $2 \mathrm{D}$ 㧍よび $3 \mathrm{D}$ 内視鏡手術群に㧍ける平均手術時間と平均出血量は、それぞれ 342 分、 $1175 \mathrm{ml}$ および 225 分、 $550 \mathrm{ml}$ であった。手術時間は $3 \mathrm{D}$ 内視鏡群において $\mathrm{p}=0.024$ で有意に短時間での手術が 可能であった。平均出血量に関しては、3D 内視鏡群で少なかったが、 $\mathrm{p}=0.257$ で両群間に有意差はなかった。また、 術後尿道カテーテル留置期間は、両群とも 6 日間で差がなかった。一方、主観的評価では手術スタッフ全員が $3 \mathrm{D}$ 内視 鏡の有用性が高いと判断した。【結論】 $2 \mathrm{D}$ 内視鏡下での腹腔鏡下根治的前立腺全摘術と比較して、3D 内視鏡手術では 手術時間や出血量を軽減できる可能性が示唆された。我々の用いたシステムの特徴は、手術スタッフ全員が立体視可能 な点にあり、術者と手術助手とのより円滑な協調操作が可能となる。また、自由度の高い針子操作も容易となる点から、 従来比較的難しいとされていた腹腔鏡手術手技も、容易に施行可能な手術になるものと期待される。

\section{AVP-026 顕微鏡下前立腺全摘除術}

\section{高槻赤十字病院泌尿器科}

德地 弘, 岡垣 哲弥

われわれは、平成 20 年末より、手術用顕微鏡を使用して前立腺全摘除術を施行し第 23 回日本 Endourology・ESWL 学会総会で 報告した。その後も症例を重权て扔り現状を報告する。

手術用顕微鏡は、三鷹光器製 MM30 倍率は3-15 倍、対面双眼にての観察が可能、焦点距離は 20-50 cm で調節可能なものを使用し、 2 名が手術台左右に着座して施行している。切開創は下腹部正中切開 $10 \mathrm{~cm}$ とし、顕微鏡のオーバーヘッドスタンドを患者左側の 足側に位置させ患者上腹部空中に䫓微鏡本体を位置させ、ほぼ 45 度チルトさせて骨盤内をのぞきこむかたちとしている。顕微鏡 手術の特徴としては、まず影微鏡には $300 \mathrm{~W}$ キセノンランプが搭載されているため、たとえ高倍率を使用していても軙めて明るく 術野を観察できるうえ、腹沿鏡に勝るとも劣らない高倍率にて術野の観察が可能なだけではなく、ロボット手術のような立体視が 可能であり、さらにMyersが最高の手術器具として使用している指も、剥離のために必要な場合には使用することができ、さらに 指が挿入することができるため、Walshが術中に腫瘍浸潤を判断する場合に重視している触覚も使用することができる。

現時点で特に顕微鏡手術において改善された部分は尖部処理であるが、顕微鏡を使用し、メス、キューサ、ツッペル、ウォーター バイポーラを使用して DVC を剥離展開していくと DVC の静脈は一本一本観察可能であり、3mmチタニウムクリップを使用して 個々に処理することが可能であり、そうすることで尿道括約筋を損傷することなく尿道括約筋表面を露出することが可能であり、 その後よく観察しながら前立腺尖部のノッチ部分から尿道括約筋を鋭的鈍的に剥離して、尿道縦走筋を露出し、耳鼻科手術で使用 する高橋氏粘膜剥離子を使用してミュラー勒带汃と前立腺実質内面加縱走筋層を剥離して、縦走筋を可及的に長く温存する功た ちでまず全面 $2 / 3$ をメッチンバーム剪刀を使用して切断し、尿道内腔で精阜の未梢端で尿道の後面を切断する。次に尿道の後方 の組織を観察しながら、前立腺組織や腫崵の存在を確認しながらデノビ工筋膜を中央で切断して直腸前面を露出し、左右の神経血 管束を処理していく。この処理を施行することにより切除断端㓌性を確保しながら尿失禁は尿道バルンを拔去直後から $99 \%$ 程度(投 稿時 10 例）に保つことができた。

倍率の拡大が手術成績にあたえる影響としては Myers らが、2.5 倍のルーペを 4.3 倍のルーペに変更することにより、より詳細 に術野が観察できるようになったために術式自体が洗練されたためとしているが、顕微鏡を使用するとさらに精細に術野を観察で き、今後より一層の術式の洗練が期待できるものと思われる。 